\title{
THE EFFECTS OF THE WORLD CPO PRICES, MACROECOMONY, AND CAPITAL STRUCTURES ON THE PROFITABILITY OF PALM OIL COMPANIES
}

\author{
Mubarok Imam Zaky*, Hartoyo Sri, Maulana Tb. Nur Ahmad \\ School of Business, Bogor Agricultural University, Indonesia \\ *E-mail: imamzakymubarok@yahoo.com
}

\begin{abstract}
The background of this study is the phenomenon known as the diminishing of the world CPO prices, analysing other external factors such as Indonesia's macroeconomy, interest rate, exchange rate towards dollars, inflation rate and capital structure of the palm oil subsector. It implements the Panel Data Regression analysis with the Fixed Effect Model to determine the external and internal factors of ROE in the palm oil subsector. The estimated doubled linear regression would result on the positive significance of the world CPO prices towards the $R O E$, the negative signifiance of the inflation rate towards the ROE, the positive significance of Growth towards the ROE, and the negative significance of Size towards the ROE.
\end{abstract}

\section{KEY WORDS}

World CPO price, macroeconomics, capital structure, oil palm, return on equity, return on assets.

Agriculture is the primary sector in Indonesia. In 2016, it contributed 13.47 percent of the GDP in total dari total keseluruhan sektor menurut lapangan usaha, with plantation as one of the subsector of agriculture contributed 3.45 percent of the GDP (Central Bureau of Statistics, 2016). Palm oil gained the first rank in the prime plantation commodity. The commodity contributed in Indonesia's economy through exports, the diminishing of poverty and employment. The main product of this commodity is crude palm oil (CPO), the main ingredient for an alternative energy to replace fossil fuels, the biodiesel. Furthermore, CPO is also used to produce other daily utilities. The data from the Directorat General of Plantation showed that the production of palm oil has increased annually, followed by the increasing volume of palm oil exports from 2012 to 2015, but it was not followed up by the annually fluctuative USD export values.

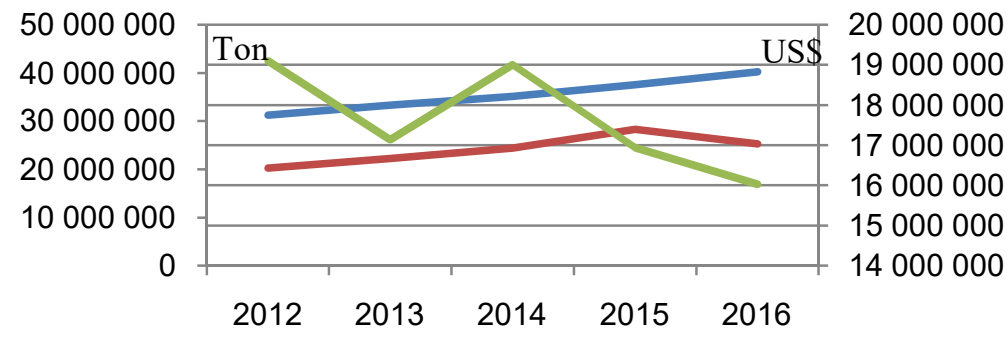

Figure 1 - Productions (blue), Exports (red) and Values of Palm Oil (green) in 2012-2016 (Source: Directorat General of Plantation of 2016, Processed)

There was a phenomenon in 2015, where the CPO commidity price experienced its lowest rank for the last five years. Executive Director of Gapki, Fadhil Hasan stated that "There were several speculations on reason for price hard to increase, which was the fall of the world crude oil price, which currently reach the total of USD30 / barrell" (Business, January 20, 2016). In 2012, the world CPO prices were around 1.061 USD per metric ton and decreased into 566 USD per metric ton in early 2016, or an average diminishing of $9,3 \%$ per year. It indicated the diminishing marginal profit of CPO, which was indicated on affecting the profitabilities of palm oil companies. Another external factor which could affect the companies' financial performances was Indonesia's macroeconomy, such as exchange rate, 
interest rate and inflation rate. Sudiyatno (2010) stated that the fundamental factor of macroeconomy reflected a systematic risk. A worsening macroeconomy condition would increase such risk and diminish the companies' performances, especially the operational performances.

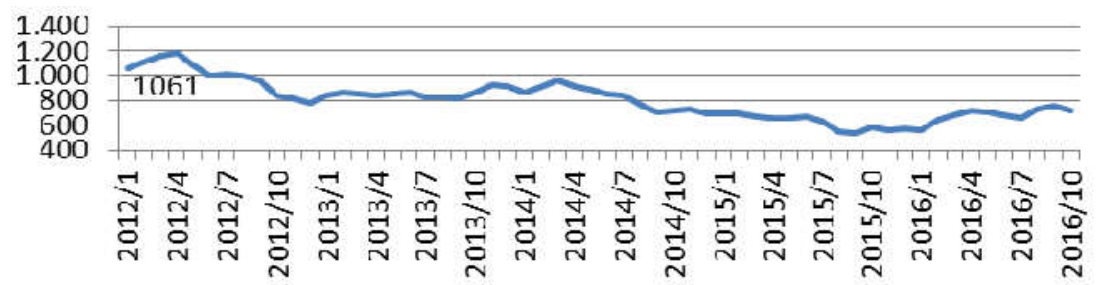

Figure 2 - World CPO Prices (US Dollar per Metric Ton) 2012-2016 (Source: IndexMundi 2016, Processed)

The internal factors, such as the capital structure, were very important for palm oil companies, as agriculture units focused on balancing the risks and the return of investments based on the companies' profitabilities. A management decision from the palm oil subsector companies stated that a funding structure would determine the companies' performances in operational activities and affect the risks (Joni dan Lina, 2010). The capital structure also influenced such performanes, as they were measured by profitablities. Therefore, several factors of those performances could be significantly affected from the companies, externally and internally.

This Study aims Analysing the effects of the world CPO prices, rupiah exchange rate, interest rate, inflation rate and capital structure to the return on equity and return on asset of palm oil companies with the period of observation for six years in 2012-2017.

\section{LITERATURE REVIEW}

The macroeconomy focused on the economic behaviors and policies which influenced consumption and investment, as well as currency and balance of trade, changing factors on wages and prices, monetary and fiscal policies, active circulation, the national budget, interests, and national debt (Dombusch et al., 2001). Sudiyatno (2010) stated that the fundamental factors of macroeconomy reflected a systematic risk. The worsening condition of macroeconomy would increase such risk, that it could diminish a company's performances. Therefore, it was safe to assume that macroeconomy significantly affected such performances. Taufik dan Sufia (2010) stated the decline of the exchange rate of rupiah towards US dollars had caused a rise of foreign debts in the amount of US dollars. The loss caused by the conflicting exchanges rates would diminish the net margin of the companies, and could be unbeneficial for the companies and investors. Sudiyatno (2010) stated that the most essential factor of macroeconomy was interests, as it affected the operational cost for the companies. Its rate, whether it was high or low, could affect the companies' pofitabilities. According to Komariyah et al (2011), inflarion also influenced the currency rate of the investments, as it would diminish the profits of the investments. The combination of worsening economic situations and the increase of production costs affected negatively on the companies' performances.

The managerial decision of the companies on the funding structure would determine the companies' opertional abilities and affect the risks (Joni and Lina, 2010). John and Lina clarified Salim dan Yadav (2012) on analysing the relation between the capital structure and the companies' performances as a research for long-term and short-term debts, the total of debts ratio and the significant relation of growth towards the ROA, ROE and EPS. As stated by Ahmad et al (2012), the research implemented the long-term and short-term debts, total of debts and the significant relation of growth as the dependent variables, while the ROA and ROE acted as the independent variables. The result showed that both short-term debts and 
total of debts had a significant realtion with the ROA, whereas the ROE had a significant relation to all the indicators of the capital structure.

\section{METHODS OF RESEARCH}

This quantitative research described facts or phenomenons statistically and featured the relations between such facts using mathematic models. The variables of this research consisted of the exchange rate of rupiah, interest rates (SBI), inflation from Bank Indonesia, and long debt to total asset, total debt to total asset, size, growth and sales growth obtained from the companies' financial reports. There were seven selected companies emittances of the palm oil subsector. It also implemented the descriptive approach that provided the conditions of those palm oil companies from 2012 to 2017. The economometric approach was also applied to analyse the influences of the world CPO prices, the macroeconomy and the capital structure towards the palm oil companies listed on BEI from 2012 to 2017. The research implemented the the panel regression data.

Panel Data Regression Method. The panel data regression model is a data which combines the cross section data and the time series data. Here is the design model.

$$
\begin{gathered}
R O E_{i t}=\beta_{0}+\beta_{1} C P O_{1 t}+\beta_{2} I D R_{1 t}+\beta_{3} S B I_{1 t}+\beta_{4} I N F_{1 t}+\beta_{5} L D A_{1 t}+\beta_{6} D A_{1 t}+\beta_{7} G R_{1 t}+\beta_{8} S I Z E_{1 t}+\beta_{9} S G_{1 t} \\
\beta_{1} ; \beta_{2} ; \beta_{7} ; \beta_{8} ; \beta_{9}>0 \beta_{3} ; \beta_{4} \beta_{5} ; \beta_{6}<0
\end{gathered}
$$

Where: $\mathrm{ROE}=$ Return on Equity; $\mathrm{i}=$ Company order; $\mathrm{t}=$ Times series; $\mathrm{CPO}=$ World $\mathrm{CPO}$ Price; IDR = Exchange Rate; $\mathrm{SBI}=$ Interest Rate; $\mathrm{LDA}=$ Long Term Debt to total Asset; DA = Total Debt to Total Asset; GR = Growth; SIZE = Size; SG = Sales Growth .

\section{RESULTS AND DISCUSSION}

We Chose pf the fixed Effect Model after conduct all the procedures to select the best model for panel data regression. We exclude random test and hausman test from the procedure because the number of variablesis greater than the number of companies used as a sample. Therefore we only use chow test in research method. The result of the chow test is shown in table 1. Based on table 1, we select the fixed effect model. The result ofmultiple linear regression had met the normality, multicolinierity heteroscedacity and autocorrelation rates.

Table 1 - Chow Test

\begin{tabular}{|c|c|c|}
\hline Effects Test & Statistic & Prob. \\
\hline Cross-section F & 5.290725 & 0.0001 \\
\hline Cross-section Chi-square & 31.946635 & 0.0000 \\
\hline
\end{tabular}

Table 2 - Analysis of the Effects of the World CPO Prices, Macroeconomy and Capital Structure on Return on Equity

\begin{tabular}{|c|c|c|}
\hline Variable & Coefficiency & Prob \\
\hline CPO & 5.984738 & $0.0000^{*}$ \\
\hline IDR & 1.499222 & 0.1656 \\
\hline SBI & 32.63468 & 0.1441 \\
\hline INF & -27.61812 & $0.0122^{*}$ \\
\hline LDA & -0.051325 & 0.9729 \\
\hline DA & -4.951325 & $0.0232^{*}$ \\
\hline GR & 1.268818 & $0.0742^{* *}$ \\
\hline SG & -0.262987 & 0.3983 \\
\hline SZ & -0.824826 & $0.0059^{*}$ \\
\hline C & --36.43514 & 0.0202 \\
\hline R-Square & \multicolumn{2}{|c|}{0.658377} \\
\hline Prob (F-Statistics) & 0.000000 \\
\hline
\end{tabular}


The estimated result of the regression model showed that independent variables with profitability bellow 5 percent and 10 percent, are world CPO prices (CPO), Inflation Rate (INF), Debt to total Asset (DA), Growth (Gr) and Size (Sz).In the other word those variables affect significantly on the return on equity of palm oil companies.

The result showed a positive, significant relation between the world CPO price variables on ROE. If there was an increase on a price, the CPO prices would increase the ROE up to 5.98. This was in line with the initial hypothesis, in which the rise of the world CPO prices would boost the companies' sales rates, especially for companies with export markets. This was also consistent with a research by Widokartiko (2015), who stated that the world oil prices affected positively on companies' profitabilities. Another significant macroeconomy variable was inflation, as the result showed a data consistent with the early hypothesis, that it would affected negatively to ROE. If there was a 1 percent increase of inflation rate, the ROE would decrease to 27.618 , as explained by Dwijayanti dan Naomi (2009), that inflation affected negatively to ROE. A high inflation rate would increase the daily prices and operational weight budget, which made a company's profit decreased.

The variable of capital structure for debt to total asset affected negatively and significantly on the ROE. A 1 percent increase of debt to total asset would decrease the ROE performance to 4.951, as stated by Riris (2014) dan Tedy (2015) on the negative debt to total asset on the ROE. This was also in line with the static trade off theory, in which a company would debt at a certain rate, and the tax shield was at the same dengan biaya-biayanya (interest expenses, provisions, and other costs realted to loans). If a company made loans excessively until exceeded its limit, there would be a risk of bankruptcy, which decreased the company's financial performance, and affected the decline of ROE. The growth variable affected significantly and positively to ROE, as a 1 percent growth would increase the return on equity up to 1.024. It also was similar with the initial hypothesis that asset growth affected positively on ROE, since palm oil companies required asset expansions as plantation areas and new land expansions to increase the production of palm oil, and Salim dan Yadav (2012) on how growth provided positive impacts on the company's profitabilities.

The size variable affected negatively and significantly on the ROE, as one size increase would decrease the return on equity to 0.7836 . The results did not aligned with the initial hypothesis because of the inefficient assets in oil palm companies such as low productive plantation and inefficient oil palm processing plants. This would result in increased production costs that reduced profitabilities, as explained by Soumadi and Suhail (2013) regarding the negative effects of size to the ROE. Based on the size of the companies, especially from their total assets, the company profits would not always recieve positive effects. Companies with small total assets did not necessarily obtain smaller profit rates compared with companies with large total assets, as long as those assets could be used efficiently by producing large quantities and minimizing production costs.

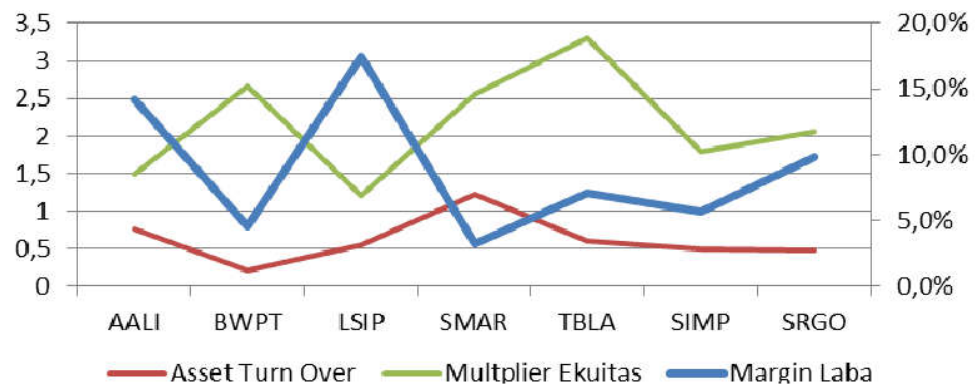

Figure 3 - Dupont Analysis on Palm Oil Companies, 2012 - 2017

The Dupont Analysis on the picture above had a low average of asset turn over of less than 1. It was used to measure the efficiency of company assets for producing sales, indicating the inefficiencies of the management on those assers and the possible problem of either the management or the production. Out of the 7 companies, only Sinarmas that had an more than one average asset turn over, meaning it was not efficient enough to manage its 
company assets, while other six companies were less efficient to manage their assets properly. However, on average rat, the palm oil companies gained a high profit from its profit margin, making it one of the companies included in the high margin industries.

\section{MANAGERIAL IMPLICATIONS}

The Company's Managerial Implications. The managerial implication for the companies' management was paying attention to world CPO price movements to predict sentiments that could affect CPO oil prices, such as country policies on imports, world trade policies regarding CPO demands, and monitored competitions from soybean oil and represed companies. Management could also pay attention to the condition of high inflation rates that could increase the company's raw material costs and reduce profitabilities, by minimizing operational efficiencies and more conservative capital structures. The result of the research would be a suggestion for companies to supervise the use of debts and manage the assets efficiently, since the companies did not optimise the use of their debts to improve the companies' performences or profits.

Investors. For the investors, this research could become a reference to a fundemental research in the palm oil sector. Investors could pay attention to the influence of the company external factors, such as the world CPO prices, meaning if there was a sentiment on the increase of the prices, the analysis should be used as a reference to invest, as it would affect the profitabilities of ROE for the companies. In addition, investors could also check the economic conditions before investing. For example, when the inflation rate was high, it would reduce the ROE, so it was advisable to delay their investments on the palm oil sector. Investors also needed to pay attention to the working capital structure of the company, before deciding on an investment in the palm oil industry, as companies with large debt levels would affect the level of profitabilities. Therefore, the research would be beneficial to the companies with rising asset growths, that would oftenly increase the companies' profitabilities.

Government. The government could pay attention to the sentiments on the influence of the world CPO oil prices, as a reference for oil palm companies in selling their products. So far, the Indonesian CPO industry was oriented to foreign price exchanges such as Rotterdam and Malaysia, which made it not being monitored by the government. Therefore, the government required its own reference to price index in determining the selling prices of $\mathrm{CPO}$. This was intended to increase the bargaining power of domestic CPO industry players at both regional and global marketing levels, and the government could have a more credible reference prices and help control the commodity prices.

\section{CONCLUSION AND SUGGESTIONS}

The results of panel data regression analysis in this study showed that the independent external from variables consisting of world CPO prices, the Inflation Rate had an effect on the ROE. Companies must be able to predict sentiments that affected the world CPO prices, such as policies from importing countries and competition from vegetable oil producers. The inflation rate and exchange rate must also be considered to undertake the right policies to manage the companies' operations.

The internal factors in this study that affected the ROE were debt to total assets, growth and sizeThe company's internal factors in debt-level decision makings were measured by the ratio of debt to total assets, therefore the company must consider the benefits (tax shield) with its costs (interest expenses, provisions, and other costs related to loans). If a company made loans excessively until exceeded this limit, it would decrease the profitabilities. Companies also needed to manage theair assets because it would increase profitabilities, but large assets did not necessarily guarantee it because in the perspective of the palm oil industry, it could not properly manage the emerging trade-offs between the cost of debt and the profits generated from the debt, causing a decrease in the companies' profitabilities. 
The R-square study produced only 65 percent for the independent variables on ROE. Meanwhile, the sis was explained by other variables. The suggestion was that this study could be used as a reference for conducting researches in other sectors or by adding measurements to independent variables, especially from internal companies. Given that the influence of the world CPO prices, that greatly affected the ROE of oil palm companies, the research was also recommended to predict the impact of palm oil export policies to the European Union, in which the operations will be creduce by 2020 for oil palm companies in Indonesia.

\section{REFERENCES}

1. Ahmad, Z., Abdullah, N. M. H., \& Roslan S. (2012). Capital Structure Effect on Firms Performance: Focusing on Consumers and Industrials Sectors on Malaysian Firms. International Review of Business Research Papers, Vol. 8 (5). 137-155.

2. Badan Pusat Statistik. 2016. Statistik Kelapa Sawit Indonesia 2012. www.bps.go.id. Akses 1 April 2018.

3. Dornbush, Fischer \& Startz, Richard. 2001. Makroekonomi.8th Edition. Jakarta: PT. Media Global Edukasi.

4. Herlinda W, 2016. Ini Tantangan Industri Sawit Indonesia pada 2016. [Diakses 4 April 2018] tersedia pada pada harian bisnis 2016: http://industri.bisnis.com/read/20160120/99/511301/ini-tantangan-industri -sawitindonesia-pada-2016.

5. Joni dan Lina. (2010). Faktor-faktor yang Mempengaruhi Struktur Modal. Jurnal Bisnis dan Akuntansi, 12(2), 81-96.

6. Memon, F., Bhutto, N. A., \& Abbas, G. (2012). Capital Structure and Firm Performance: A Case of Textile Sector of Pakistan. Asian Journal of Business and Management Sciences, Vol. 1 (9): 09-15

7. Sudiyatno. 2010. Peran kinerja perusahaan dalam menentukan pengaruh factor fundamental makroekonomi, resiko sistematis dan kebijakan perusahaan terhadap nilai perusahaan. Disertasi. Universitas diponegoro Semarang.

8. Salim, M. \& Yadav, R. (2012). Capital Structure and Firm Performance: Evidence from Malaysian Listed Companies. Procedia - Social and Behavorial Sciences 65, pp. 156 166.

9. Siti Komariyah, Julaenah. M. Chudori.2011. Return Saham, Inflasi, dan Struktur Kepemilikan terhadap Risiko Investasi. Jurnal Keuangan dan Perbankan, Vol 15, No.3.hlm 376-391

10. Soumadi M \& Suhail M. (2011). Capital Structure and Corporate Performance Empirical Study on The Public Jordanian Shareholding Firms Listed in the...EuropeanScientificJournal Vol. 8 (22) 173-189.

11. Taufik, M., \& Sulfa, A. (2010). Pengaruh kandungan informasi laporan arus kas, inflasi, dan nilai tukar rupiah terhadap return saham (capital gain) dan deviden tunia (studi pada perusahaan manufaktur yang terdaftar di bursa efek Indonesia). Jurnal Akuntabilitas.

12. Widokartiko, Bayu (2015) Dampak kinerja internal dan kondisi makro ekonomi terhadap profitabilitas pada perbankan. Masters thesis, Institut Pertanian Bogor. 